\title{
Sunrise release of larvae from the palinurid rock lobster Jasus edwardsii
}

\author{
A. B. MacDiarmid
}

University of Auckland, Leigh Marine Laboratory, R. D. Leigh, Northland, New Zealand

\begin{abstract}
The diel timing of hatching of larvae from female rock lobsters Jasus edwardsii (Hutton) was investigated in the laboratory and in the field during October, when the majority of larvae hatch. Captive female rock lobsters, carrying external eggs, hatched naupliosoma larvae over 3 to $5 \mathrm{~d}$. Each day, the majority of larvae hatched just after sunrise. Naupliosoma moulted into Stage I phyllosoma larvae within $30 \mathrm{~min}$ of hatching. Naupliosoma and Stage I phyllosoma larvae were not found in the plankton sampled from above an aggregation of female rock lobsters, bearing external eggs, until sunrise. Mean densities of Stage I phyllosoma found are the highest recorded for this species. Low catches of Stage I phyllosoma in previous studies may be due to noncoincidence of sampling and patches of larvae, caused in part by the simultaneous hatching of larvae from aggregated females at sunrise.
\end{abstract}

Planktonic larvae of homarid and palinurid lobsters are notoriously patchy in distribution (e. g. Ritz, 1972; Rimmer, 1980; Phillips, 1981; Harding et al, 1982; Cobb et al, 1983). One of many mechanisms that may promote patch formation is the synchronus release of larvae from females which are themselves patchy. In captive female Homarus gammarus, larvae are released a few minutes after sunset (Ennis, 1973; Branford, 1978). No similar laboratory work has been done on any palinurid lobster but anecdotal reports suggest that hatching in some species occurs during the night (Batham, 1967; Silberbauer, 1971). No field confirmation of a restricted hatching period has been documented for any palinurid or homarid lobster.

In this study, time of hatching of larvae of the palinurid rock lobster Jasus edwardsii is reported from both laboratory and field investigations. These were carried out at the Leigh Marine Laboratory and in the adjacent marine reserve in north-east New Zealand.

Timing of Study. Female Jasus edwardsii in the reserve have a well defined egg-bearing season from late May to late October (MacDiarmid, unpubl.). Over the last $4 \mathrm{wk}$ of the 1982 egg-bearing season the percentage of mature female rock lobsters carrying eggs fell from $89 \pm 2 \%$ (SE) to $5 \pm 2 \%$ (SE). By late September, in the 1983 egg-bearing season, the percentage of females carring eggs reached $97 \pm 1.5 \%$ (S E). Laboratory and field observations for this study took place between 12 and $15 \mathrm{~d}$ later when it was noticed that some females in the reserve had hatched their larvae. The first larval stage of Jasus edwardsii, the naupliosoma (see Lesser, 1974, for a description of larval stages), lasts only 0.5 to $1 \mathrm{~h}$ before moulting into the Stage I phyllosoma (Batham, 1967). Occurrence of naupliosoma larvae in the plankton therefore indicates recent hatching

Laboratory observations. Nine female Jasus edwardsii carrying late stage eggs (Tarring, 1980) were obtained from the reserve population late in the 1983 egg-bearing season and held in a large communal tank. Indirect natural light entered the tank-room through side windows. Three females observed to hatch some larvae on the 12th of October 1983 were placed singly in $120 \mathrm{l}$ aquaria that day. A hollow concrete block was provided for shelter in each tank. Fresh seawater $\left(15.8^{\circ} \mathrm{C}\right)$ flowed through the aquaria at a rate of $61 \mathrm{~min}^{-1}$. Water discharged from the tank was filtered through $280 \mu \mathrm{m}$ mesh sieves to retain any larvae. These sieves were replaced at $20 \mathrm{~min}$ intervals over one $24 \mathrm{~h}$ period. Sieve contents were flushed into bottles and stored into $10 \%$ formalin in seawater. The contents were later examined for naupliosoma larvae. To minimise disturbance to female rock lobsters during the night, a flashlight with red filters (Kodak no. 36 and 25) was used to provide light when replacing sieves and when checking tanks for the presence of naupliosoma. $J$. edwardsii are least sensitive to this part of the visible spectrum (Meyer-Rochow and Tiang, 1981). At dawn, visual observations supplemented information obtained from sieve samples. On subsequent days, additional observations were made at dawn on six further females when they began to release larvae, but sieve samples were not collected.

Field observations. I used replicated visual count techniques to determine seasonal changes in the distribution and density of Jasus edwardsii (MacDiarmid, unpubl.). Female rock lobsters bearing external eggs congregate on the deepest parts of coastal reefs within the reserve over the 5 mo egg-bearing season. On one 
deep reef, such females reached mean densities of $51 \pm 9.2$ (SE) per $500 \mathrm{~m}^{2}$ by late September 1983 and comprised $77 \pm 6 \%$ (SE) of all individuals. Zooplankton samples were taken from near this reef between 1800 to $0800 \mathrm{~h}$ on the 14 to 15 th of October 1983 using a conical plankton net of mouth area $0.5 \mathrm{~m}^{2}$ and a mesh size of $500 \mu \mathrm{m}$. At 1 to $2 \mathrm{~h}$ intervals through the night and $0.5 \mathrm{~h}$ intervals after sunrise, 3 replicate vertical hauls of the full water column $(20 \mathrm{~m})$ were taken a few m down-current of the reef. When the current changed direction with the tide, the other side of the reef was sampled. At slack water, samples were taken directly over the top of the reef. Samples were preserved in $10 \%$ formalin and later the entire sample was examined for larvae.

Results: Laboratory observations. 1131, 1292 and 28967 naupliosoma hatched in $24 \mathrm{~h}$ from the 3 female rock lobsters respectively. The majority of these larvae hatched just after sunrise in a $20 \mathrm{~min}$ period between 0550 and 0610 h (Fig. 1). Ninety-seven, 93 and $95 \%$ of all larvae from the 3 respective females hatched at this time. Very few larvae hatched prior to $0550 \quad 10.09 \%$, $0.69 \%$ and $0.05 \%$ of all larvae from the 3 females) but small numbers hatched for $1 \mathrm{~h}$ after the peak period. The remaining 6 females also released most of their larvae just after sunise. When releasing larvae, female rock lobsters clung to the side or top of the concrete shelters and raised their tails vertically into the water current. The 5th pereiopods were used to 'comb and squeeze' the egg masses. The pleopods were then beaten violently for 1 or $2 \mathrm{~s}$ releasing a 'swarm' of naupliosoma larvae. Beating of pleopods and associated hatching of larvae took place at intervals of approximately 1 to $2 \mathrm{~min}$ for the first $15 \mathrm{~min}$ but continued intermittently for $1 \mathrm{~h}$. Immediately upon hatching, naupliosoma larvae swam towards the dawn light. Thirty naupliosoma larvae were extracted from 1 tank immediately after hatching and placed in Petri dishes containing fresh seawater. Some moulted into Stage I phyllosoma larvae within a few minutes and all did so within half an hour. Individual female rock lobsters were left in their aquaria for $1 \mathrm{wk}$ until all eggs had hatched. Hatching took place just after sunrise each day and took 3 to 5 d to complete.

Results: Field data. Larvae did not occur in plankton samples until just before sunrise when high numbers of Stage I phyllosoma larvae were present in the water column (Fig, 2), Three naupliosoma larvae were captured, one each in the 0530,0600 and $0640 \mathrm{~h}$ samples. Their presence indicates that the Stage I phyllosoma caught in the same hauls had probably moulted only recently from the naupliosoma stage. Low numbers of phyllosoma continued to be caught until the last sampling occasion. Numbers of larvae in replicate hauls were variable, particularly at the peak of larval

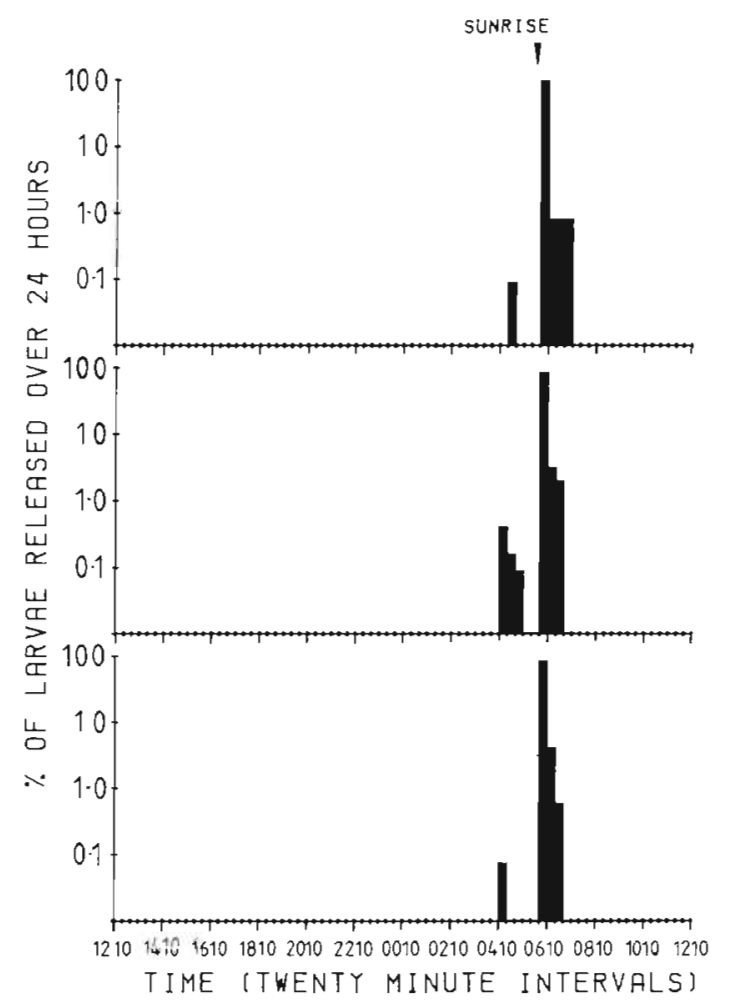

Fig. 1. Jasus edwardsii. Percentage of naupliosoma larvae released every 20 min over $24 \mathrm{~h}$ from 3 captive females. $\mathrm{Y}$ axis in log-scale. Total ' $n$ ' for each female, from top to bottom: 1131, 1292 and 28967 larvae

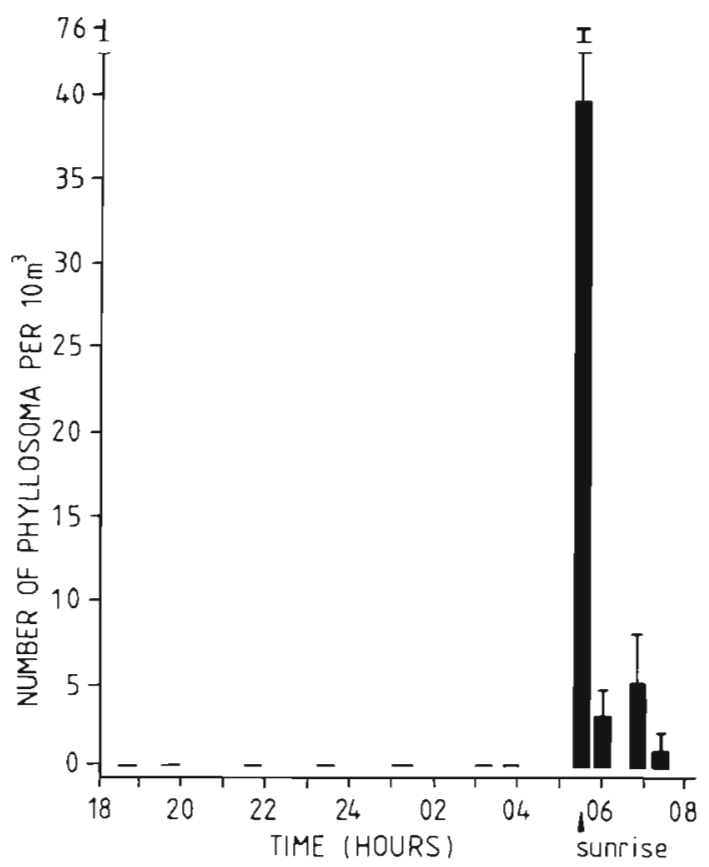

Fig. 2. Jasus edwardsii. Temporal changes in abundance (mean no. $\pm \mathrm{SE} \mathrm{m}^{-3}$ ) of phyllosoma larvae in the plankton sampled from above a benthic aggregation of females carrying external eggs 
abundance at $0530 \mathrm{~h}$ when in the 3 replicate hauls 114 , 2 and 2 larvae were caught.

Discussion. There is some debate as to whether the pre-phyllosoma stages reported in a number of palinurid species are normal free-living larvae or result from premature rupture of eggs in the laboratory (Phillips and Sastry, 1980). Capture of naupliosoma larvae in the plankton suggest that this is a normal stage in Jasus edwardsii. Because there is only a brief time interval between the first two larval stages, the coincidence of time of peak hatching of naupliosoma in the laboratory and peak catch of Stage I phyllosoma larvae in the plankton strongly suggest that hatching of larvae does occur close to sunrise in this species. This contrasts with $H$. gammarus in which hatching occurs just after dusk.

McKoy and Leachman (1982) documented the occurrence of aggregations of female Jasus edwardsii carrying late-stage eggs in areas of strong water current. They suggested that females move to such areas to release larvae into the current and thereby increase the numbers carried away from coastal reefs. Currents are tidal and reversible in the marine reserve at Leigh and it is possible that the hatching of larvae at dawn may be modified depending on the presence, direction and strength of these currents.

Peak densities of Stage I phyllosoma larvae obtained in the plankton $\left(3910 \mathrm{~m}^{-3}\right)$ are 2 orders of magnitude higher than previously obtained in this species (Lesser, 1978) and are similar to the high-density patches of Stage I phyllosoma of Panulirus cygnus found off the coast of Western Australia (Rimmer, 1980). Rimmer suggested that these patches of larvae may be related partly to the uneven distribution of ovigerous females on the reef below at the time of hatching. The low catches of Stage I phyllosoma of Jasus edwardsii made by previous workers in the marine reserve at Leigh (Kingsford, unpubl.; Foster, unpubl.) may be due to the non-coincidence of sampling and patches of larvae, caused, in part, by the simultaneous hatching of larvae from aggregated females at sunrise.

Acknowledgements. I thank B. A. Foster, J. H. Choat, J. Booth, J. Annala and 2 anonymous referees for reviewing the manuscript. I am grateful to W. J. Ballantine for the use of facilities at the Leigh Marine Laboratory. This work was supported by a scholarship from the Fisheries Research Division of the New Zealand Ministry of Agriculture and Fisheries.

\section{LITERATURE CITED}

Batham, E. J. (1967). The first three larval stages and feeding behavior of phyllosoma of the New Zealand palinurid crayfish Jasus edwardsii (Hutton, 1875). Trans. R. Soc. N. Z. Zool. 9: 53-64

Branford, J. R. (1978). The influence of daylength, temperature and season on the hatching rhythm of Homarus gammarus. J. mar biol. Ass. U. K. 58: 639-658

Cobb, J. S., Gulbransen, T., Phillips, B. F., Wang, D., Syslo, M. (1983). Behavior and distribution of larval and early juvenile Homarus americanus. Can J. Fish. aquat. Sci. 40: $2184-2188$

Ennis, G. P. (1973). Endogenous rhythmicity associated with larval hatching in the lobster Homarus gammarus. J. mar. biol. Ass. U. K. 53: 531-538

Harding, G. C., Vass, P. W., Drinkwater, K. F. (1982). Aspects of larval American lobster (Homarus americanus) ecology in St. Georges Bay, Nova Scotia. Can. J. Fish. aquat. Sci. 39: $1117-1129$

Lesser, J. H. R. (1974). Identification of early larvae of New Zealand spiny and shovel-nosed lobsters (Decapoda, Palinuridae and Scyllaridae). Crustaceana 27 (3): 259-277

Lesser, J. H. R. (1978). Phyllosoma larvae of Jasus edwardsii (Hutton) (Crustacea: Decapoda: Palinuridae) and their distribution off the east coast of the North Island. New Zealand. N. Z. Jl mar. Freshwat. Res. 12: 357-370

McKoy, J. L. and Leachman, A. (1982). Aggregations of ovigerous female rock lobster, Jasus edwardsii (Decapoda: Palinuridae). N. Z. JI mar. Freshwat. Res. 16: 141-146

Meyer-Rochow, V B., Tiang, K. M. (1981). Seeing lobsters are correctly treated. Catch '81 8 (3): 17-21

Phillips, B. F. (1981). The circulation of the south-eastern Indian Ocean and the planktonic life of the western rock lobster. Oceanogr mar Biol. A. Rev. 19: 11-39

Phillips, B. F., Sastry, A. N. (1980). Larval ecology. In: Cobb, J. S., Phillips, B. F. (ed.) The biology and management of lobsters, Vol. 2, Ecology and management. Academic Press, New York, p. 11-57

Rimmer, D. W. (1980). Spatial and temporal distribution of early stage phyllosoma of western rock lobster, Panulrus cygnus. Aust. J. mar Freshwat. Res. 31: 485-497

Ritz, D. A. (1972). Factors affecting the distribution of rock lobster larvae (Panulirus longipes cygnus) with reference to variability of plankton net catches. Mar Biol. 13: 309-317

Silberbauer, B. I. (1971). The biology of the South African rock lobster, Jasus lalandii (H. Milne-Edwards), 1. Development. Investl Rep. Div. Sea Fish. S. Afr. 92: 1-67

Tarring, S. (1980). Egg developmental studies. Catch '80 7 (7): 21

Accepted for printing September 29, 1984 